Current Issues in Middle Level Education

Volume $25 \mid$ Issue 1

Article 7

2020

\title{
What Drives your Spirit and Commitment to Middle Level Education? Exploring a Middle School Mindset
}

Nancy B. Ruppert

UNC-Asheville,nruppert@unca.edu

Follow this and additional works at: https://digitalcommons.georgiasouthern.edu/cimle

Part of the Curriculum and Instruction Commons, and the Junior High, Intermediate, Middle School Education and

Teaching Commons

\section{Recommended Citation}

Ruppert, Nancy B. (2020) "What Drives your Spirit and Commitment to Middle Level Education? Exploring a Middle School Mindset," Current Issues in Middle Level Education: Vol. 25 : Iss. 1 , Article 7.

DOI: $10.20429 /$ cimle.2020.250107

Available at: https://digitalcommons.georgiasouthern.edu/cimle/vol25/iss1/7

This description is brought to you for free and open access by the Journals at Digital Commons@Georgia Southern. It has been accepted for inclusion in Current Issues in Middle Level Education by an authorized administrator of Digital Commons@Georgia Southern. For more information, please contact digitalcommons@georgiasouthern.edu. 
Ruppert: Exploring a M iddle School Mindset

\title{
What Drives your Spirit and Commitment to Middle Level Education? Exploring a Middle School Mindset
}

\author{
Nancy B. Ruppert \\ University of North Carolina, Asheville
}

\begin{abstract}
Over the past two years, middle school advocates have been sharing their thoughts on the following prompt: "What drives your spirit and commitment to middle level education?" The purpose has been to capture 'the spirit' of middle school educators?' From these stories five characteristics emerged that can help us consider how to promote the next generation of middle school leaders. Perhaps using the findings from this exercise can help us advocate for the next generation of middle school leaders. For the purpose of this study, middle school refers to those who work with 10-15 year olds and includes intermediate schools, a K-8, middle schools, junior highs, or 9th grade academies.
\end{abstract}

\section{Introduction and Background}

In 2018, Southeast Middle Level Professors held a symposium in South Carolina to share ways to promote middle level education within our respective institutions and districts. A small group of middle level professors and graduate students began to explore the possibility of promoting a middle level mindset to advocate for the next generation of middle level leaders (Coleman \& Ruppert, 2019). While there is a growth mindset and a fixed mindset (Dweck, 2006), we were referencing the inner spirit of middle level educators as a middle school mindset and "seeking ways to promote a middle school mindset in theory and in practice" (Ruppert, 2019, p. 19). Later that year I invited colleagues to share "What drives your spirit and commitment to middle level education?" and "How can we capture "the spirit of middle school educators?" I received feedback from 24 middle level advocates.

In spring 2020, Southeast Professors of Middle Level Education (SEPOMLE) designed a symposium in North Carolina to celebrate and advocate for the next generation of middle school leaders. We had planned a two-day drive-in conference in Asheville, and along with many venues and presentations, COVID 19 disrupted our plans. One of my roles in the conference was to share insights from our previous symposium and the stories of people who participated in a survey. The purpose was to help broaden our inspiration by describing a middle school mindset.

\section{Related Research to A Middle School Mindset}

The Association for Middle Level Education (AMLE) provides us with guiding principles, essential attributes, goals and characteristics of what makes exemplary middle schools. This we believe (in press), originally published in 1993, has been a document that has been revised and grown as middle level education has blossomed and research has deepened what we know about how to serve 10-15 year olds in exemplary middle schools. We, as 
professors, look to this document as the foundation for implementing middle school practices and use it to prepare the next generation of leaders. We are thrilled that AMLE has updated this document and will be sharing it this fall.

Additionally, AMLE provides electronic resources including research, webinars, articles, summaries, professional development and support for our preservice teachers, principals, schools and professors on all topics related to middle level education. As an AMLE affiliate, our own Current Issues in Middle Level Education Journal supports our work as Professors of Middle Level Education (NAPOMLE) so that we have access to current and past research and literature that contributes to the field of middle level education and preparation. A middle school mindset has been described in our AMLE literature for decades.

In 2003, John Lounsbury and Gordon Vars described the first 30 years of the middle school movement, including the following: "The future of middle level education, of public schooling, indeed, of all life on this planet depends on the human spirit..[and] middle school educators have correctly been recognized for the degree to which that spirit characterizes their work" (p. 13). Paul George (2011) describes the characteristics of sharing, cooperation, trust, and personal care that initially drove and still drives a middle school mindset. Sandy Camelli (2017) describes mindset as a classroom teacher as "an attitude with intention" (n.p.). Dru Tomlin (2019) shares a webinar on creating great middle schools for principals by being a building "mover". He provides teachers and administrators with specific skills needed, including: advocacy and agency, humor, and a school that implements multiple curricular tools for creating caring environments. Andrew Maxey (2019) shares how his school district embraced three ways of thinking: knowing and sharing research, advocating for middle school as an opportunity, and being the change. In 2015, I interviewed principals in North Carolina and found they looked for teachers who were joyful, patient, loved middle school students, understood the middle school concept, were collaborators and embraced reflection and positive change. But how do we share a middle school mindset with those who may be new to teaching and/or new to working in middle schools? And who would we look to for sharing this idea of a middle school mindset?

\section{Methodology}

I conducted a qualitative survey study, using grounded theory (Charmaz, 2001), and to collect data, I started with convenience sampling (Cochran, 1977) and included the use of a snowball sampling method (Wright \& Stein, 2005). My questions were and still are, "What drives our spirit and commitment to middle level education?" and "How can we capture "the spirit of middle school educators?" I asked people to share their thoughts about middle school children, their teachers and staff... the magic of it. .... and why it matters. I invited middle school professors, middle school advocates, middle school alumni of our institution and asked those I reached out to share the link with people they believe portray the idea of a positive spirit and commitment to working with this age group. Initially I reached out to 113 middle level advocates. To date, AMLE Keynote leaders, Legacy Leaders, AMLE Board Members, Beginning and Veteran middle level Teachers, Principals, Professors, have shared their views.

Elements of grounded theory (Charmaz, 2001), a qualitative approach to identifying themes and patterns guide researchers through a process of reading, re-reading, and looking for themes, was used. In the first round, I collected 24 stories. Some of the middle school advocates had over 40 years of teaching experience and other advocates were in their first few years of teaching. It didn't seem to matter. That simple question, "What drives your spirit and 
commitment to middle level education?" revealed beautiful imagery of who young adolescents are, how advocates came to be teachers and administrators, and just how precious this age group is, and how precious the gift of working with them is. As we develop a middle school mindset, these stories capture what it looks like.

In my first read, I was looking to see if there were any patterns that jumped out to me, a qualitative tactic. Using grounded theory, I took several first reads, then began looking for patterns. I found five. The stories, like I had hoped, were personal and insightful. I have tried to summarize findings and share a few quotes and insights into what I believe characterizes a middle school mindset.

\section{Findings}

\section{Mindset 1: Many Roads Lead us to Become Middle School Teachers}

While some of us made the decision early to work with young adolescents in middle schools, there are more than a few who accidentally stumbled into her nest. What if we hadn't landed in a middle school because "that was the only job open"; or what if we hadn't happened to be with a professor who said, "You know, you might love middle school!" Or what if that middle school teacher we had hadn't said, "You would make a great middle school teacher!"

Perhaps we need to provide more intentional opportunities for K-6 and secondary licensure candidates to experience middle school students. Our Collegiate Middle Level Association (CMLA) is an excellent place to start. I would imagine as university professors we have seen the spark in pre-service candidates' eyes, the wild side, the mavericks who will help set middle school students' learning and experiences on fire. Perhaps we need middle school clubs for those interested in becoming teachers. Perhaps we as middle school teachers and leaders need to become mentors and advocates for our own profession. Our first element associated with a middle school mindset encompasses the idea that if we had not seen middle school, or someone hadn't pointed it out to us, we may not have realized its value.

Hear our colleagues' words:

I didn't choose middle school teaching, it chose me. After having taught all the elementary grades from first grade forward, I got "promoted" to teaching at the middle level. Suddenly I had the "big" kids, and instantly I fell in love. My sixth graders not only got my jokes, they actually laughed at them. They were just finding their voices in the world and were passionate about making it a better place. (Keynote Speaker)

I began my college education convinced that I was going to be an elementary school teacher. Then junior year came around and I realized that I should probably be involved in some sort of club or activity at my university rather than just working and going to classes. The club that I found was CMLA-CMU, sponsored by Dr. Norma Bailey. Norma had such a passion for middle level education that I was immediately hooked in. I have never looked back. (AMLE Board Member - Teacher)

\section{Middle School Mindset 2: This Magical Age Inspires Hope and Passion}

When I asked people to share what drives your spirit and commitment to middle level education the plethora of adjectives provide a vast array that examines the infinite characteristics of this amazing age group. With each of the expressions of who these young people are, I believe we stand in awe of them, and I wish we could bottle their energy. It is this spirit and commitment 
that provides a backdrop for how to work with them. It is possible that knowing the creative possibilities that make up this age group could be a selling point to promote middle level education. A middle school mindset embraces the unique, inspiring, and sometimes frustrating world of young adolescents. And those who work with them appear to be energized by their hope.

They are awkward, funny, bright, dramatic, overly confident at times while completely unsure at others...yearning for connections, budding citizens, vulnerable, emotional, playful, serious, challenging, earnest in their beliefs, highly ethical, highly aware of inequity, simple and complex. They exude excitement, curiosity, sincerity, intensity, creativity; they are inventive, highly imaginative, and incredibly interested in the world around them. And so, what do we do with this? I believe we must be researchers of this age group, digging deeply into brain research, theories on young adolescents, and current research that defines who these young people are in the 21 st century. And we must share the what they produce. We must tell their stories, their ideas, their passions and we have the awesome opportunity to help lead them to "their why."

Hear the words of our colleagues:

They are weird and funny, unique and often stinky (and I mean that in a dual sense - both behavior and body). They have boundless energy, curiosity and vulnerability (NAPOMLE Board Member - Professor)

There are three general groups of middle school students. Some students who are very mature, some who are very immature, and then there are some who are sometimes very mature and at other times very immature. Personally, I believe I still fall into the third classification. I guess that's why I love middle school so much (Affiliate Director)

\section{Middle School Mindset 3: We Actually Learn from Them}

When I asked advocates to capture "the spirit of middle school educators," what I found is that we learn much from them. It is this passion for working with this age group that allows us to expand our own world view, our own compassion for equity and inclusion, and our own craft as teachers. There is no doubt that working with young adolescents is challenging. When I asked advocates to share their thoughts about middle school children, their teachers and staff... the magic of it. ... why it matters, I found many comments related to how much we, as teachers, learn from our students. It is this magical gift that by working with this age group, those of us who see them as growing and developing, we are committed to helping them "become." Perhaps we too are becoming?

Hear the words from our colleagues:

They held me to a higher standard. Early adolescents, middle level students, have made me a better teacher, a better leader, and a better human being. (AMLE Board Member)

We squander the key moments in a young adolescent's life when we could support healthy, active identity development. Instead the tradition is to minimize thought, exploration and concern. I love middle school for the possibilities and the times when it is actualized. (Professor)

\section{Middle School Mindset 4: We Must Find More Ways to Collaborate to Help Them Find Their Purpose}


Across this exercise, I found some very good advice for us as professors of middle level education. No one mentioned that teaching this age group is easy. In fact, most of us consider it one of the most difficult jobs anyone will find. Insights from our advocates suggest our passion and our commitments, our collaborative experiences must continue. We must find ways to collectively make a difference, uphold the beliefs that our students are worth every ounce of energy we expend, and help them become our next leaders.

Being part of a team, belonging, building a community can happen in individual classrooms. Collaborating with colleagues makes this experience exponentially better. While we teach teaming as a tool for common practices, assessments, events, and exercises, may we never forget that teaming is about family, caring for one another, and finding ways together to make a difference with students.

Hear the words of our colleagues:

We need to wildly help them find their passions, help them discover who they are and lead them down the path towards who they want to become. It takes unique, passionate people to teach them. (AMLE Board Member - Principal)

I know as a middle level teacher I can make a great contribution to what society will become as I nurture these budding citizens and offer them space to explore who they are, who they want to be, and give them tools to do so. (District Technology Facilitator)

\section{Middle School Mindset 5: Hope, Commitment, and Joy Lead Us Forward}

And finally, from the stories of middle school advocates, schools that work with young adolescents and the students themselves are our passion and our commitment. This sample of advocates illustrates the importance, the power, and the potential impact middle school age students have on our changing world. I also found that participants willingly shared the joy of working with this age group.

Middle school is more than curriculum; it is more than a group of students. It is a community where hope and joy thrive. The good humor, laughter, inspiration middle school students experience is contagious. When teachers are committed to this age group, they find many examples of hope. It is time to share that joy, the hope, and our own commitment to middle level education, to middle school students, to those who choose to work with this age group.

Hear the words of our colleagues:

There is no other place I would rather spend my time. (Principal)

I see middle school as the sweet spot for inspiration. This is the time in their life that they start to realize their own capacity for decision making and that those decisions then impact their future. I believe the relationships we build with middle school students are the key to our success with them and I love that those relationships continue to build into their adulthood when they reach back out to you and remind you of the impact you had. (NAPOMLE - Professor)

Many years after my school had opened as a middle school, the Principal retired. In his honor a reunion was arranged and teachers from near and far traveled to attend this event. It was remarkable to hear and read the testimonies. In a nutshell, all agreed that we lived through a shining moment in education, and were fortunate to have taught in a 
school that lived up to the bold ideals of best middle schooling. That inspiration for me has lasted a lifetime. (Legacy Leader)

\section{Closing}

From Legacy Leaders to beginning teachers, AMLE Board of Trustees, principals, superintendents, researchers, district staff, and keynote speakers, based on these stories, a middle school mindset includes a belief and trust in the potential of young people. In these stories, in this time to come together, to share our ideas, our passions, to ignite hopes and practices that address equity and inclusion, we must start with a mindset that our kids matter: whoever they are, wherever they are. The characteristic of This we believe that is so prevalent throughout these topics is "leaders are committed to and knowledgeable about this age group, educational research and best practices" (AMLE, 2010, p. 36).

In addition, we matter: whoever we are, wherever we are. As professors of middle level education, middle school truly is where our next leaders who will change the world are. May we be the facilitators who inspire the next generation of middle level leaders who are in our classrooms at the university, who are in schools as teachers, assistant principals and principals, and to the children who are entering middle schools all over the world. This mindset relates to This we believe, "leaders demonstrate courage and collaboration" (AMLE, 2010, p. 36).

When we provide students, teachers, and administrators with support, joy, innovation, creative opportunities, imagination and hope, we help build the next generation of caring, passionate, deliberate, visionary leaders. The structures that have been in place, especially in light of COVID 19 and in light of institutional racism that continue to plague our schools, may change; but maybe everything needs to change, except the mindset of those who believe in this amazing group of young people and who have the vision to move schools towards a more equitable, caring, place. My hope is that we use these findings, these quotes, these ideas, and these passions to compliment the characteristics of exemplary middle schools and promote a middle school mindset that inspires those new to middle school and those who have lived the passion to share a common joy and support for one another in their efforts to advocate for young people and those who work with them.

\section{Next Steps}

Our plan is to continue to gather data around this theme using a Google Form. If you would like to participate in more dialogue and sharing of a middle school mindset, do not hesitate to contact me.

We will ask:

- How many years you have worked with middle school age students

- Where you were trained to work with this age group,

- Your current role

- How did you come to be a middle school teacher/administrator/staff?

- How would you characterize the students you work with?

- How would you describe what they need to learn?

- What do you perceive is the most critical thing we need to think about when we are working with this age group?

- Why does middle school matter? 
- What drives your spirit and commitment to middle level education?

- How do you take care of yourself as a teacher?

- Anything else?

Can we take these five elements: how we got here, who young adolescents are, what we learn from them, how they learn, and how we share hope... to develop a middle school mindset that establishes positive, equitable places for the next generation of leaders? This is what this study revealed:

- There is no one path to becoming a middle school teacher

- There is no one prototype of a middle school student.

- Building relationships cannot be under-estimated. We believe this time in their lives is critical. We must be intentional that what we are teaching them can transfer into their dreams.

- We, as teachers and leaders, must always be learning with and from our students.

- We must maintain hope, commitment, and joy.

\section{References}

Cameli, S. (2017). Making middle school philosophy work: Philosophy vs. mindset. AMLE Magazine. Retrieved from http://www.amle.org/BrowsebyTopic/WhatsNew/WNDet.aspx?ArtMID=888\&ArticleID $=842$

Charmaz, C. (2001). Grounded theory: Methodology and theory construction. International encyclopedia of the social \& behavioral sciences. 6396-6399.

Cochran, W. (1977). Sampling techniques, 3rd ed. Wiley.

Coleman, B., \& Ruppert, N. (2019). Collaboration in the middle: Middle grades to higher education promoting, advocating, igniting support for middle schools. Current Issues in Middle Level Education, 24(1), 1-3

Dweck, C. (2006). Mindset: The new psychology of success. Random House.

George, P.S. (2011) The American middle school movement: Taking the long view. Middle School Journal, 43(2), 44-52.

Lounsbury, J. H., \& Vars, G. F. (2003). 30 Years of advocating for young adolescents: The future of middle level education: Optimistic and pessimistic views, Middle School Journal, 35(2), 6-14.

Ruppert, N. (2017). What does it take to be a middle school principal in the 21 st century? [Presentation] A presentation at the Governor's Teacher Network Research Symposium. 
Ruppert, N. (2019). Personalized professional development plans. Current Issues in Middle Level Education, 24(1), 19-23.

Tomlinson, D. (2019). The ABCs of the middle grades mindset: 10 terms to create a great school. AMLE Webinar [webinar] Retrieved from http://www.amle.org/ServicesEvents/Webinars/101619/tabid/1141/Default.aspx

Wright, R., \& Stein, M. (2005). Snowball sampling. Encyclopedia of Social Measurement. 495500 . 